\title{
The Ruralization of the World
}

\author{
Monika Krause \\ Goldsmiths College \\ m.krause@gold.ac.uk
}

Public Culture 25/2: 233-248

-- Please cite published version --

We live, we are told, in a world that is urbanizing and that is urbanizing at a rapid pace. It is often cited that, according to the United Nations, about half of the world's population is now living in cities. By 2050 "the world population is expected to be 67 per cent urban” (UN2011).

According to Edward Soja and Miguel Kanai "the spatial reach of city-based societies, economies and cultures to every place of the planet” is unprecedented (Soja and Kanai 2007: 54). "More than ever before it can be said that the Earth's entire surface is urbanized to some degree, from the Siberian tundra to the Brazilian rainforest to the icecap of Antarctica, perhaps even to the world's oceans and atmosphere we breathe. ... (Soja and Kanai 2007: 62).”

These numbers, and the diagnosis of urbanisation, are used to underscore the importance and urgency of scholarly and policy initiatives on 'urban' themes. They are also used to legitimate discussing all types of social problems as urban problems: It is currently fashionable to discuss, for example, infrastructure as "urban" infrastructure, disasters as "urban" disasters, and social justice as the right to the city.

This lens of "urbanization" invites us to analyse change, the emergence of something we do not (yet) know, as the expansion of one thing we already think we know, the city. The notion of the "city" and the "urban" have come to function as a place-holder for a bundle of assumptions about specific kinds of places and specific lifestyles, usually opposed to the "rural", closely associated with assumptions about modernity, and capitalism, usually opposed to the pre-modern or traditional. The bundling of assumptions about the urban tends to be rather similar, whether urbanization is then seen as a 'good' thing or a 'bad' thing.

But this paper argues that to fully make sense of current socio-spatial transformations, it is worth at least trying out the opposite perspective, and analyse them from the perspective of that which is supposedly acted upon, or being transformed. To take a simple example from discourses about urbanization, as we see people move into cities why do we assume only the people to change? Conversely, if we see people who live in cities visit the countryside, why do we expect only the countryside to change? If the city is endless, as is claimed, for example, in the title of a recent publication by the LSE's Urbanage Project (Burdett and Sudjic 2007), it is also the countryside. If the whole world is urbanizing, it must also be ruralizing. 
Only when we ruralize the way we think, can we fully disaggregate the different distinctions that have been subsumed under the categories of urban and rural, and think about the different ways they can be put together in forms of social settlement. Only from this perspective can we examine the different ways they are put together again as part of contemporary socio-spatial transformations.

We can see that dimensions of both urbanity and rurality are central to the way social fault lines are currently being reshaped, but this is happening in complicated and new ways. Only if we complement a focus of urbanization with recognition of ruralization, can we see peasants in growing cities, new forms of improvisation in declining cities, and the tensions emerging between agricultural livelihoods on the one hand and wilderness on the other hand, when the wild becomes invested with meanings and values from the outside.

\section{The Intellectual Imperialism of the Urban}

Discourses about "the city" and "the urban" have been shaped by the way a specific group of people imagined, a few, very specific places - if the city was first Paris or Berlin, it was later Chicago, and then, more recently LA (Gieryn 2006, Robinson 2006). The debate about cities has always been overlaid with normative concerns about modernity - it was in cities that observers found individual freedom, the public sphere, and cosmopolitanism on the one hand, and it was in cities that they found anomie and anonymity, crime and poverty on the other hand (see also Gans 2009). These discourses about the city and the urban in turn have come to play an important role in refracting the way we imagine all kinds of social problems, and this seems as en vogue today as it was in the late 19th century; they also shape the responses and solutions we consider.

There has been a lively debate about how exactly to describe and re-describe, imagine and reimagine the "city". Partly as a result of these debates, this conversation has come to include consideration of cities in the global south, though, as Matthew Gandy and Jennifer Robinson have pointed out, this consideration has really only come to include a few iconic neighbourhoods of a few iconic mega-cities of the south, such as Lagos and Mumbai (Gandy 2005, Robinson 2006).

There has been broader reflection on the ethnocentrism of urban theory and a call to include a broader set of cases (Simone 2004, 2010, Robinson 2006, Hilgers 2012) but scholars have rarely given up on the category of the urban itself. There has been much discussion of the politics of how and by whom the urban is represented but much less on the costs of framing political questions, questions about social organization and, indeed questions about place, as urban questions in the first place.

It has been useful to shift the focus from cities as categories to urbanization as a process (Schmid 2006, Brenner and Schmid 2012, Brenner 2012). This perspective has given us some traction on heterogeneity within the "global" or "planetary urban": Cities - dense, large settlements- appear as special cases within an "urban society". In their "urban portrait of Switzerland" Roger Diener and his colleagues, for example, distinguish between cities, resorts, quiet zones and alpine fallow-lands (Diener et al. 2006) 
But even if heterogeneity is analysed, the term urbanization still points us in the direction of analysing spatial forms from an urban perspective. In fact, it is unclear what exactly is meant by the word "urban" in accounts of what these authors call the "global" or the "planetary urban". While it may be true that there is no outside of capitalism, it is unclear why we need to approach this whole of social relations as an "urban" one. It may be true that the most remote places are connected to and through market forces - but this argument has been made not just for the present day, but also for the early modern era (see e.g. Braudel 1992) and it is unclear what this diagnosis adds to an analysis of the present specifically. While it may be true that there has not been a rural for a long time, it is also true that we have never been urban in the way urbanists imagined us to be.

If place, or material situatedness, matters - and this has been the starting point for the interest in the urban in the first place - we cannot just rethink the city, we need a broader understanding of variation in socio-spatial arrangements and we need to examine these with a more open mind.

A focus on urbanization as a process has made us see some kinds of unlikely combinations between dimensions of the urban and the rural: based on an analysis of urbanization, we see wifi in remote areas, garbage in oceans, and suburbanites in the countryside. A focus on ruralization brings us not only urban agriculture and urban wildlife but also farmers in suburbs, and boring towns. A ruralization approach also allows us to study new developments that only become visible once we abandon the narrow focus on urbanization such as the emergence of new forms of improvisation in the face of failing infrastructures.

\section{Places, Solidarities, Livelihoods, Political Institutions}

One response to the problems of the category of the "urban" and the contrast to the "rural" on which it depends has been to point at the in-betweens, and the grey zones - to think of the distinction between urban/rural as a continuum rather than a categorical distinction. But this idea of the continuum leaves the bundling performed by the original binary relatively intact while blunting the analytical edges contained within it. ${ }^{1}$

Another track is more productive: Rather than blur these distinctions, we can disaggregate the elements supposedly associated with each side so that we can use them better to analyse how they are combined in socio-spatial formations. We need to distinguish between properties of places, solidarities, people, practices, and forms of governance and notice that they do not always map onto each other in ways the dichotomy between rural and urban would suggest.

Disaggregation is partly guided by the concerns associated with the original categories - if for the nation-state, this is best captured by asking about the elements territory, authority and rights (Sassen 2007), attention to the urban would seem to add specifically properties of places, of forms of social solidarity and of the ways people are linked to their livelihoods. We can then ask questions about these elements using properties formerly associated with the urban and the rural, such as "dense", "isolated", "creative", or "anomic"

Places can be described in terms of physical properties, density, and architecture and in terms of the people who live there. Solidarity is here not a positive term but is meant to describe the different ways people are linked to each other. Solidarity in this sense could include hostility, 
conflict or ignorance. The term livelihood could capture all types of connections between people and their material and symbolic means of subsistence, and here we should include those highly mediated by markets and technology and bear in mind that they have always been mediated by technology. Forms of governance include rights, practices and formal political institutions.

Only distinguishing the properties of physical places and the properties of solidarity, for example, allows Philip de Boeck to see "urbanism without architecture" and "the invisible city" in Kinshasa (de Boeck and Plissart 2006). The distinction between place and forms of solidarity is also thrown in relief by the case of the wandering city, such as Addis Ababa until 1892, where large groups of people moved together (Fletcher 1998). Livelihoods rarely work in synch with the physical properties of places but remain connected to them in complex ways. Physical places often painfully do not coexist with political boundaries. The administrative separation of cities and suburbs in the United States, for example, drains the city of resources related to those who use it (Frug 1996). ${ }^{2}$ For the distinction between physical places and social solidarities, consider also the tensions around second-homes in many rural areas, who often do not fully contribute to infrastructures they use, if only periodically (Rye 2011). In any given place, we would expect different forms of solidarities, livelihoods and forms of governance to overlap in ways that can themselves be analysed.

\section{The Rural in the Urban}

Consider the 'douars' of Marrakesh. Taking their name from a "collection of tents, a temporary village", they have been the destination of poor residents from the environs; residents of these settlements bring their animals into the city; their donkeys shape traffic in the city. They produce fruit and vegetables, for their own consumption but they also sell it across town, which Mohamed El Faiz calls a form of revenge by the residents of the douars on the city, for the pollution, which is inflicted on their fields (El Faiz 2002).

Many residents of the squatter settlements of Maputo, until very recently one of the fastest growing cities in Africa, also grow their own food, sometimes on fields in or close to the city, sometimes travelling long distances to fields they have access to. If these forms of livelihood are not what we have been taught to expect in a city, neither is the form of solidarity. These settlements are not at all anonymous places, despite the large number of people who live there: every ten houses have a spokesperson, and ten of these ten house units have another spokesperson. These are spaces of close surveillance. This is true both in the everyday, when residents monitor comings and goings of outsider for security purposes - if a resident receives an overnight visitor he or she must report this to a representative. The surveillance matters also in the political sense, when these same local committees are counted upon to provide votes for the ruling party. Residents reject the notion that they live in an illegal settlement, but without formal recognition of their rights to the land, they know to be careful in their interactions with government. $^{3}$

Phenomena like these are often discussed as part of a failed or incomplete urbanism specific to Africa, as areas that are too incompletely integrated and too incompletely connected by infrastructure to count as fully urban. This discourse has been powerfully challenged by work in 
the last decade by Simone (2004, 2012), Robinson (2006), de Boeck and Plissard (2006) Myers (2011), who have firmly reinserted these spaces into thinking about cities.

Such settings are not "what is not yet urban", but rather part of "what is urban". If the city today is also these settlements, the douars of Marrakesh (El Faiz 2002), and the gecekondus of Istanbul - and if these areas are a part of the urbanization of people, they are also a part of the ruralization of space.

These strange combinations of dimensions of urbanity and rurality do not just occur in the global south. Elements of the rural have always persisted in western European cities, and we need to rethink how urban cities were at any time, in any place. As Hope Mirrlees put it, in a 1919 poem: "Paris is a huge homesick peasant" (Mirrlees 1919).

People carry the past in their habitus, and the places they come from; the immediate and the more distant past, regional and international journeys. Berlin, for example, has a welldocumented history of international migration; but it is also a city shaped by the entry of rural and small-town Germans. The discontinuities of German history remain part of the city. "White" Berliners themselves carry generations of refugees within them, that thorough archaeology, or just careful interviewing can reveal (see e.g. Liebman 2002). The migrations from rural and small-town Germany continue and remain reproduced in social networks - a phenomenon earlier arrivals respond to with a discourse about and against "Swabians", loathed for their relative wealth but also for their small-town culture (Frank 2008).

The rural appears within the city not just as a lifestyle choice, a new integration of the sustainable, as it is expressed and analyzed in some discussions on urban farming in Western cities. It is not just an accessory, re-introduced on entirely urban grounds. These are 'real' and not 'fake' discontemporaneities, to use Ernst Bloch's distinction (Bloch 1962), and even the term discontemporaneities might imply too strong a sense of teleology.

Dimension of the rural move into the city despite the sometimes violent attempts to eradicate them. Slum clearance projects, for example, often make it impossible to keep livestock or maintain informal relations (e.g. Pontrandolfi 2002). Urbanization remains incomplete and is violent in its ongoing enforcement. As long as access to livelihood and basic needs requires also informal arrangements, there is an in-built resistance to urbanization.

Patterns of investment and disinvestment are reordering which places are rural and urban in terms of density and size (see Oswalt 2005, 2007), but in this process also produce new forms of rurality. The American rust-belt has been a space of disinvestment for decades, a trend that has been dramatically sharpened by the foreclosure crisis. In cities like Detroit and Cleveland, urban spaces have lost population and have become empty, and overgrown. New forms of improvisation have emerged, relating to schooling, social services and transport (Vogel 2005). Cities or what is left over from what used to be urban spaces become used as resource mines as residents engage in agriculture but also collect copper and wood for reuse (Hocking 2005). To evoke an old typology of economic geography, these cities are becoming the site of "first sector" activities.

These practices can be reinserted on top of older practices of not-quite urban subsistence. In Soviet cities, the dacha had always provided a backdrop to industrial forms of livelihood 
(Chekhovskik 2005). Following subsequent crisis from 1991 onwards, more residents in the former Soviet Union turned to supplementing other sources of income with the fruits of land they had access to, and with fish and game from surrounding areas, spending weekend to whole weeks working the fields away from the city (Miturich 2005)

\section{The Absent Center of Ruralization}

Ruralization has no centre from which it emanates. Villages are not the stable, natural starting point of human civilization as which they are sometimes portrayed. This portrayal is fuelled by a comparison to barbaric nomadism in discussions of early human history - a portrayal that equates hunter-gatherer societies and nomads living with domesticated animals - and still serves state projects to make space legible at the expense of nomadic populations like sinti and roma, kurds, and beduins in different parts of the world (Kazanov 1994). This portrayal is also taken up by the contrast between Gemeinschaft and Gesellschaft, with echoes powerfully in sociology, and, in an iverted way in anthropology (Bausinger 1996).

As Raymond Williams has put it “The 'country way of life' has included the very different practices of hunters, pastoralists, farmers, and factory farmers and its organisation has varied from the tribe and the manor to the feudal estate, from the small peasantry and tenant farmers to the rural commune, from latifundia and the plantation to the large capitalist enterprise and the state farm” (Williams 1975: 1).

There has always been variation within the rural, including variation in how people with different movements relates to the same place. In some areas, farmers form concentrated settlements and leave every morning to travel to their fields; in other areas, they live close to their respective fields and are thus more spread out (Levi 2006 [1945], Mandal 2001). Farmers coexist with groups who move with their animals during the year, sometimes to exploit the change of the seasons, sometimes simply because they were not able to afford enough land close together (Kazanov 1994; Haldimann 2008). For shepherds the term "village" has a different meaning than it has for farmers, and both are very different from that ascribed to it by the owner of a secondhome.

The rural is not just a site of variation but has always also been a site of conscious political intervention: The colonisation of land by peasants has a long history as part of political projects. The creation of artificial villages has a history in colonial times; they were also adopted by various African Governments, in the 1970s and 1980s (de Waal 1991, Cannon Lorgeb 1999, Rogers and Kikula 1997) and they are part of land reforms in other contexts, such as Southern Italy (King 1973).

But to point to the tensions within the rural is not the same as to dismiss it as mere discourse (Halfacree 2004, 2012); indeed the opposition between the real and the discursive and all attempts to mediate between the two lead us in the wrong direction. Deconstruction is often used against the idea of the rural but it can at the same time be used against the urban. If we can say, "there has not been an extra-discursive rural for a long time", we can also say, "we have never been urban” echoing Latour (Latour 1993). That does not mean that the rural or the urban is or has just been ideology. The question is rather, again, what are the elements of the rural and how 
can they be disaggregated so we can look for empirical phenomena that would otherwise be obscured.

In acknowledging the variation within the rural, and taking its dimensions seriously, a ruralization-theoretical approach is much less prone to simplistic notions of the rural than the discussion on urbanization, which requires the rural as an eternal foil for urbanization to insert itself into, to corrode, to gobble up at the same time as it declares it already gone. We can even acknowledge that in some contexts cities have preceded the formation of villages (Braudel 1992: 484, citing Jane Jacobs 1970).

Wild and agricultural, for example, are two such dimensions of the rural, which are in conflict, and we might add the biosphere as a third dimension (Sassen and Dotan 2011). Conflict between the people who live off the land and the wild can come in the form of droughts, avalanches, and diseases. They take on a special form if the wild is invested with outside valuation by conservationists, or tourists. This has a long history in Africa, for example, where the creation of national parks has excluded a range of uses by local populations (Carruthers 1994, Wolmer 2007). This tension between the agricultural and the wild is also played out during efforts to resettle predators in the Alps, an effort often resisted by farmers, shepherds and hunters (Battran 2011, blickpunkt.ch 2006).

There are other combinations of rurality and urbanity that are not quite visible from an urbanization perspective: Consider the curious socio-spatial pattern produced by Germany's policy of refugee dispersal: refugees, often with complex urban-rural biographies, are assigned to camps in rural areas in Germany; the buildings are former pubs or military barracks; the population is diverse, but not dense. The setting is isolated; but this isolation is of course quite different from an isolation of a pastoral kind; it is reinforced by a law, which has created the refugee-specific crime of leaving one’s assigned area (Selders 2009).

\section{The Rural in the Urban in the Rural}

Concepts like “counter-urbanization” (Berry 1980, Champion 1989), “rurbanization” (Bauer and Roux 1976) and "deurbanization" seem to challenge assumptions about urbanization and promise a recognition of ruralization, but these terms have somewhat ironically been used to paint a picture about the spread of cities beyond their boundaries through populations that are assumed to be thoroughly urbanized, into areas that are assumed to have previously been disconnected, agricultural, and/or unsettled.

Counter-urbanization is thus imagined as the colonisation of the rural by the urban, through suburbs, city regions, and sprawl (for interesting early examples, see also Braudel 1992: 281). We see here the clearest example of an opportunistic oscillation between geographic and social definitions of the urban in the urbanist literature so that, when people move to cities it is the place that dominates the interpretation of the phenomenon and people are assumed to transformed; when people move to rural areas, it is the people that dominate the interpretation and the place that is assumed to be transformed. When we find supposedly urban phenomena in supposedly rural areas, these are not just a proof that urbanization happens everywhere. We must 
allow for the possibility that dimensions of the rural pose more resistances here (Halfacree 1994) and not only in the sense that a discourse of the rural is central to people's decision to move.

Even in one of the paradigmatic cases of counter-urbanization as urbanization - an England that is known to have had a particular path of industrialization, which rather radically transformed the countryside (see Negt and Kluge 1981), a more complex picture emerges on close inspection. Ray Pahl's classic study "Urbs in Rure” (1965) has a title that suggests urban imperialism and has chapters like "London in Hertfordshire", but his analysis show, in fact, the complexity of the patterns that emerge. There remains a division between commuters and those who live and work locally. New jobs related to providing services to middle class commuters, enable a perpetuation of agricultural lifestyles, a pattern we have also long seen in alpine regions (Baetzig 2003; Bünz Efferding and Efferding 2002).

To add complexity, it is not just the commuters who have moved - from the city - a lot of the local workers have migrated to the area from other parts of the countryside. It is important not to overlook international migration to the countryside, and, more specifically, international migration to do farm labor (Halfacree 2009, Hoggart and Mendoza 2004).

In many contexts outside the US suburbs are also villages; the città diffusa in Italy cannot just be read as sprawl but is also an agricultural zone, with a more diverse and sustainable agriculture than the rural zone, and a population that maintains very strong and very local ties (Ferrario 2009). German suburb-villages are shaped by a division between suburbanites and villagers, a division that finds its expression in conflicts about seemingly trivial matters of lifestyle around the inconveniences of cow dung on the street but also in persistent educational inequalities between both groups.

\section{Boring Cities}

Most residents of cities do not live anywhere near the centres of New York, Chicago, LA, Lagos or Mumbai. According to the UN, half of the world's 3.6 billion urban dwellers (50.9 per cent) lived in cities or towns with fewer than half a million inhabitants. Such small cities account for 55 per cent of the urban population in the more developed regions and for 50.2 per cent of the urban population in the less developed regions (UN 2011; Hilgers 2012).

These cities usually do not get much scholarly attention. Scholarly work travels more easily if attached to one of a number of exemplary cases, or model systems, which are familiar to scholars from other studies (Howlett and Morgan 2010, Craeger, Lunbeck and Wise 2007). Urban studies is a clear case of this, with its focus on a few selected and usually very large cities (Guggenheim and Krause 2012, see also Gans 2009).

We can rediscover “ordinary cities” as Jennifer Robinson has suggested in an important intervention (2006). But this may not necessarily mean restoring to them the excitement, creativity, and innovation Robinson associates with “urban modernity”. Ordinary cities, or medium sized cities, in the West, or in Africa, might have these characteristics or they might not. They might have some of these characteristics but not others. They might be boring cities (see e.g. Ray and Wieland 2001). 
The discussion about Los Angeles (in contrast to Chicago) has already raised the possibility of urban spaces without 'cityness' (e.g. Scott and Soja 1996), but what is needed is a serious consideration of a broader set of cases and a broader conception of possible dimensions of variation and change.

\section{Conclusion}

Traditional notions of the city have rested on theories, fears and hopes associated with modernity combined with observations in a few very specific, iconic places; attempts to rethink the city have rarely given up on the notion of the city itself. Reflection on the politics of how the urban has been represented rarely engage the politics of framing social issues or even spatial issues as urban issues.

Theories of urbanization have put dense settlements into a broader socio-spatial context, but that means it has become unclear why this broader context should be described as urban. It would be an interesting task for the sociology of knowledge to explore why the category of the urban is so hard to let go of and in fact proliferates so much - the contribution of factors internal to the academic landscape, the broader policy and funding environment, and the lifestyle preferences of participants of the discourse would all be worth investigating.

It is time to ruralize our thinking: While it maybe true that the most remote places are connected to and through market forces, it is also true that we have never been urban in the way urbanists imagined us to be: informal social relations, the natural, the problem of food and livelihoods, the need, complex dependencies that nevertheless enable survival. Dimensions of the rural enter more and more spaces and they enter in unlikely places - as capital leaves Western cities, for example, new forms of informality take over. As public sector cuts hit in European economies, connecting infrastructure is lost. Rural-to-urban migrants return to the countryside, or rely heavily on subsidised from family farms.

Rather than dismiss either the urban or the rural as ideology, I suggested that the way forward is to distinguish dimensions formerly associated with the urban and the rural from the perspective of the rural and use these to explore variations among forms of settlement. Only based on a distinction between the dimensions of the urban and the rural can we see how they are recombined as properties of solidarities, places, governance and livelihoods.

The study of forms of settlement from the perspective of ruralization begins with better description but it need not be descritptive and atheoretical. But as we link the description of places to theory, the relationship of specific forms of settlement to capitalist development - or processes of diferentiation or other hypothesis about social and institutional change for that matter - needs to be examined rather than assumed.

\section{References}

Baetzig, Werner 2003. Die Alpen - Geschichte und Zukunft einer europäischen Kulturlandschaft. Munich: C.H.Beck.

Battran, Martin. 2011. “Luchse in der Kulturlandschaft.” Biologie in unserer Zeit 41(5):306-315. 
Bauer Gerard and Roux Jean-Michel. 1976. La rurbanization ou la ville éparpillée. Paris: Edition du Seuil.

Bausinger, Herman. 1990 [1961]. Folk Culture in a World of Technology. Bloomington: Indiana University Press.

Berry, Brian. 1980. "Urbanization and Counterurbanization in the United States." The Annals of the American Academy of Political and Social Science, September 451/1: 13-20.

Bloch, Ernst. 1962. [1935]. Erbschaft unserer Zeit. Frankfurt: Suhrkamp.

Braudel, Fernand. 1992. [1979]. Civilization and Capitalism, 15th-18th Centuries. Berkeley: University of California Press.

Brenner, Neil 2012. Theses on Urbanization. Public Culture 24/3

Brenner, Neil and Christian Schmid. 2012. "Planetary urbanization,” in Matthew Gandy ed., Urban Constellations. Berlin: Jovis, pp. 10-14.

Bünz-Efferding, Anke and Wieland Efferding. 2002. Die Alpen-Sherpas. Geschichten vom Hüttentragen im Oberen Iseltal. Berlin: Haymond Verlag.

Cannon Lorgeb, Christy. 1999. The Experience of Villagisation: Lessons from Ethiopia, Mozambique, and Tanzania. London: Oxfam.

Carruthers, Jane. 1995. The Kruger National Park: a Social and Political History. Pietermaritzburg: University of Natal Press.

Champion, Anthony G. (ed). 1989. Counterurbanization: the changing pace and nature of population deconcentration. London: Edward Arnold.

Champion, Anthony G., and Graeme Hugo. 2004. New forms of urbanization: beyond the urbanrural dichotomy. London: Ashgate.

Chekhovskik, Irina. 2005. "The Dacha Phenomenon", in Philip Oswalt (ed) Shrinking Cities, Volume 1, International Research. Ostfildern-Ruit: Hatje Cantz, pp. 494-497.

Creager, Angela .N.H, Elizabeth Lunbeck,. and M. Norton Wise. 2007. Science without laws: Model systems, cases,exemplary narratives. Chapel Hill: Duke University Press.

Dahly, Darren L., and Linda S. Adair. 2007. "Quantifying the urban environment: a scale measure of urbanicity outperforms the urban-rural dichotomy.” Social science \& medicine 64(7):1407-1419.

De Boeck, Filip, and Marie-Fracoise Plissart. 2004. Kinshasa: tales of the invisible city. Ludion: Royal Museum for Central Africa.

Diener, Roger, Jacques Herzog, Marcel Meili, Pierre de Meuron, Christian Schmid (ed). 2006. Switzerland: an urban portrait. Basel: Birkhäuser.

El Faïz, Mohamed. 2002. Marrakech: patrimoine en péril. Paris: Actes Sud. 
Ferrario, Viviana. 2009).“Agropolitana: Countryside and Urban Sprawl in the Veneto Region (Italy)” Revija za geografijo - Journal for Geography, 4-2, 129-142.

Fletcher, Roland. 1998. “African urbanism: scale, mobility and transformations.” In Graham Connah (ed.) Transformations in Africa: Essays on Africa's Later Past, London: Leicester University Press: 104-38.

Frank, Charlotte. 2008. "Berlin Schwaben raus!" Sueddeutsche Zeitung, 23.12.2008, http://www.sueddeutsche.de/panorama/berlin-schwaben-raus-1.374212.

Frug, Gerald. 1996. “The Geography of Community.” Stanford Law Review, 48(5): 1047-1108.

Gandy, Matthew. 2005. “Learning from Lagos.” New Left Review 33:37-53.

Gans, Herbert J. 2009. "Some Problems of and Futures for Urban Sociology: Toward a Sociology of Settlements.” City \& Community 8(3):211-219.

Gieryn, Thomas F. 2006. "City as Truth-Spot: Laboratories and Field-Sites in Urban Studies." Social Studies of Science 36(1):5-38.

Guggenheim, Michael and Krause, Monika. 2012. "How Facts Travel. The Model Systems of Sociology.” Poetics 40: 101-117.

Haldimann, Hans. 2008. Bergauf Bergab. Documentary. 101 min. Switzerland.

Halfacree, Keith. 2004. "Rethinking'rurality'.” In Anthony Champion, Graeme Hugo, and others. (ed) New forms of urbanization: Beyond the urban-rural dichotomy. London: Ashgate, pp. 285-304.

Halfacree, Keith. 2008. “To revitalise counterurbanization research? Recognising an international and fuller picture”, Population, Space and Place 14(6):479-495.

Halfacree, Keith. 2012. "Diverse Ruralities in the 21st Century: From Effacement to (Re-) Invention.” in László J. Kulcsár and Katherine J. Curtis (eds) International Handbook of Rural Demography. Springer: Dordrecht, pp. 387-400.

Hilgers, Mathieu. 2012. "Contribution à une anthropologie des villes secondaires" in Cahiers d'Etudes africaines, LII (1), 205, pp. 29-55.

Hocking, Sctott. 2005. Scrappers, in Philip Oswalt (ed) Shrinking Cities, Volume 1, International Research. Ostfildern-Ruit: Hatje Cantz, pp. 470-478.

Hogart, Keith, and Cristobal Mendoza. 1999. “African immigrant workers in Spanish agriculture.” Sociologia Ruralis 39(4):538-562.

Howlett, Peter, and Mary S. Morgan. 2010. How well do facts travel? The dissemination of reliable knowledge. Cambridge: Cambridge University Press.

Hugo, Graeme, Anothony Champion, and Alfredo Lattes. 2003. “Toward a new conceptualization of settlements for demography." Population and Development Review 29(2):277-297.

Jacobs, Jane. 1970. The Economy of Cities. New York: Random House. 
Kazanov, Anatoly M. 1984. Nomads and the Outside World. Cambridge: Cambridge University Press.

King, Russel. 1973. Land reform: the Italian experience. London: Butterworth.

Latour, Bruno. 1993. We have never been modern. Cambridge: Harvard University Press.

Levi, Carlo. 2006. [1945]. Christ stopped at Eboli. London: Penguin.

Liebman, Irina. 2002. [1982]. Berliner Mietshaus. Berlin: Berliner Taschenbuch Verlag.

Mandal, R. B.2001. Introduction to rural settlements. New Delhi: Concept Publishing Company.

Mirrlees, Hope. 1919. Paris - a Poem. London: Bloomsbury Press.

Miturich, Sergei. 2005. "Subsisting in Yuzha", in Philip Oswalt (ed) Shrinking Cities, Volume 1, International Research. Ostfildern-Ruit: Hatje Cantz, pp. 521-531.

Myers, Garth A. 2011. African Cities: Alternative Visions of Urban Theory and Practice.

London: Zed Books Limited.

Negt, Oskar and Alexander Kluge. 1981. Geschichte und Eigensinn. Frankfurt/ Main:

Zweitausendeins.

Oswalt, Philipp. 2005. Shrinking Cities, Volume 1, International Research. Ostfildern-Ruit: Hatje Cantz.

Oswalt, Philip. 2007.Shrinking Cities, Volume 2, Interventions. Ostfildern-Ruit: Hatje Cantz.

Pahl, Ray E..1965. Urbs in rure: the Metropolitan Fringe in Hertfordshire. London: London School of Economics and Political Science.

Pontrandolfi, Alfonso. 2002. La vergogna cancellata : Matera negli anni dello sfollamento dei Sassi. Matera: Altrimedia, 2002.

Robinson, Jennifer. 2006. Ordinary Cities. Between Modernity and Development. Routledge, London.

Rogers, Peter. J. and Idris S. Kikula. 1997. Policy Implications on Environment: the case of villagisation in Tanzania. Uppsala: Nordiska Afrikainstitutet.

Roth, Juergen and Rayk Wieland. 2001. Öde Orte. Ausgesuchte Stadtkritiken: von Aachen bis Zwickau. Leipzig: Reclam.

Rye, Johan F..2011. "Conflicts and contestations. Rural populations' perspectives on the second homes phenomenon", Journal of Rural Studies 27, 263-274.

Sassen, S.askia and Natan Dotan. 2011. "Delegating, not returning, to the biosphere: How to use the multi-scalar and ecological properties of cities”, Global Environmental Change, 21: 823834.

Sassen, Saskia. 2006. Territory, Authority, Rights: From Medieval to Global Assemblages. Princeton University Press. 
Schmid, Christian. 2006. "Theory" in Diener, R., J. Herzog, M. Meili, P. de Meuron, C. Schmid (ed) Switzerland: an urban portrait. Basel: Birkhäuser, pp. 163-225.

Scott, Allen J. and Edward W. Soja (eds). 1996. The City: Los Angeles and Urban Theory at the End of the Twentieth Century. Berkeley: University of California Press. 1996.

Selders, Beate. 2009. Keine Bewegung! Die 'Residenzplicht' für Flüchtlinge -

Bestandsaufnahme und Kritik. Berlin: Flüchtlingsrat Brandenburg \& Humanistische Union.

Eigenverlag, http://www.residenzpflicht.info/report-inhalt/, accessed August 62012.

Simone, AbdouMaliq. 2004. For the City yet to Come: Changing African Life in Four Cities.

Durham: Duke University Press.

Simone, AbdouMaliq. 2010. City life from Jakarta to Dakar: movements at the crossroads. London: Taylor \& Francis.

Soja, Edward and Miguel Kanai. 2007. “The urbanization of the world.” In R. Burdett and D. Sudjic (2007) The endless city, London: Phaidon, pp. 54-69.

Swissinfo. 2006. Nicht jeder will den Bären in der Schweiz, swissinfo, 15.4.2006, http://www.swissinfo.ch/ger/Home/Archiv/Nicht_jeder_will_den_Baeren_in_der_Schweiz.html? cid=5127914 [accessed 6.8.2012].

United Nations. 2012. World Urbanization Prospects: The 2011 Revision. New York: Department of Economic and Social Affairs, Population Division.

Vogel, Stephen. 2005. "DIY City Services", in Philip Oswalt (ed) Shrinking Cities, Volume 1, International Research. Ostfildern-Ruit: Hatje Cantz, pp. 462 - 470.

Williams, Raymond. 1975. The country and the city. Oxford: Oxford University Press.

Wolmer, William L. 2007. From Wilderness Vision to Farm Invasions-Conservation and Development in Zimbabwe's South-east Lowveld. London: Routledge. 
1 Some of the best critiques and analyses of the category of the urban, and the rural/urban dichotomy have come from demographers (Hugo and Champion 2004; Hugo, Champion and Lattes 2003; Dahly and Adair 2007). But their efforts are shaped by the specific intellectual and practical problems they pose themselves - and they are ultimately limited by being a response towards these specific problems: Demographers seek to categorise people and regions so that they hold up as stable statistical independent and dependent variables. They thus, for professional reasons, have to try to find ways to categorise places on maps and people together and hope that there is a meaningful relationship between population and territory.

2 But note that Frug does not advocate trying to match communities and administrative boundaries as a solution, but rather develops more complex proposals for an equitable coexistence of levels of governance.

3 These observations are based on fieldwork conducted with Clapperton Chakanetsa Mavhunga in Maputo in October 2011. This research was supported by the Poiesis Fellowship and the BMW Foundation.

\title{
Author Information:
}

Monika Krause teaches sociology at Goldsmiths College, University of London. She has recently published "How Facts Travel: The Model Systems of Sociology" (with Michael Guggenheim, Poetics, Spring 2012) and is currently finishing a book manuscript on humanitarian relief.

\begin{abstract}
:
We live, we are told, in a world that is urbanizing and that is urbanizing at a rapid pace. This diagnosis is used to underscore the importance and urgency of scholarly and policy initiatives on 'urban' themes. There has been much discussion of the politics of how and by whom the urban is represented but much less on the costs of framing political questions, questions about social organization and, indeed questions about place, as urban questions in the first place. To fully make sense of current socio-spatial transformations, we need to also analyse them from the perspective of that which is supposedly acted upon, or being tansformed. Only when we ruralize the way we think, can we fully disaggregate the different distinctions that have been subsumed under the categories of urban and rural, and think about the different ways they can be put together in forms of social settlement. Only from this perspective can we examine the different ways they are put together again as part of contemporary global transformations.A focus on ruralization brings us not only urban agriculture and urban wildlife but also farmers in suburbs, and boring towns. A ruralization approach also allows us to study new developments that only become visible once we abandon the narrow focus on urbanization such as the emergence of new forms of improvisation in the face of failing infrastructures.
\end{abstract}

